\title{
Sharia Banking Opportunities and Challenges in the Digital Era
}

\author{
Baidhowi \\ Lecturer of Islamic Law, Faculty of Law, Universitas Negeri Semarang (UNNES), Indonesia \\ Email: baidhowi@mail.unnes.ac.id
}

\begin{abstract}
The Indonesian government in the era of President Joko Widodo had a big vision in the digital economy sector. Jokowi is targeting Indonesia in 2020 to become the largest digital economic power in ASEAN, with e-commerce transaction projection values reaching 130 million US dollars. Indonesia's population currently reaches 262 million people. More than 50 percent or about 143 million people have been connected to the internet throughout 2017, report the Indonesian Internet Service Providers Association (APJII). In era disruption in the progress of financial technology, there has been a problem how are the opportunities and challenges of Islamic banking in the digital era? with SWOT analysis revealing the opportunities and challenges of using financial technology in Islamic banking services. The use of financial technology that is in line with regulations makes good opportunities to improve the quality of Islamic banking services for the convenience and security of customers. However, the application of financial technology also contains challenges for banks. The presence of financial technology raises a more variative financing model with lower costs and fast service. So that the existence of the role of banking institutions can be displaced/ threatened.
\end{abstract}

\section{Keywords—Islamic Banking; Financial Technology (Fintech); Regulation}

\section{INTRODUCTION}

Indonesia's population currently reaches 262 million people. More than 50 percent or around 143 million people have been connected to the internet throughout 2017, at least according to the latest report from the Indonesian Internet Service Providers Association (APJII). The development of internet technology is used to develop services, this is an innovation that is enough to provide opportunities for the banking sector in developing and introducing their products. One example of a banking product developed through the internet is Internet banking.

A product or service may have been available for some time, but how consumers learn about the product for the first time and decide whether to adopt it. Howard and Shet (1967) said that the theory of consumer behavior can be seen from the process of input in the form of marketing mix stimuli and environment that will produce output in the form of attitude, intention (behavioral intention), and purchase behavior (buying behavior) of banking products.

In the era of disrupting the effects of consumer/ customer behavior, customers are very easy to turn to other companies. Importantly, cybersecurity, namely the government and companies must work together in providing security for transactions carried out. Online network connection with offline.

Technological and internet developments that are increasingly fast and agile, should not only serve as threats and obstacles but must be used as opportunities and challenges to spur creativity and produce something that will help human work more regularly and directed. The presence of technology that is so fast, must be utilized in improving Sharia banking services for consumers with more competent facilitation and not in contravention of Sharia principles.

Now what needs to be considered is the changing behavior of its customers. The behavior of customers in the digital age really wants their business to be faster, safer and also save time. The customers like the way that transactions are no longer limited by time and place, this is actually a challenge for banks in this digital world. An equally worrying challenge is the trend of decreasing margins. This is due to the very tight competition among business actors which causes a decrease in credit quality and so due to the policy on the size of the loan base rate. To deal with these challenges the bank must make adjustments to changes in basic needs. Therefore, it is very important to know how the opportunities and challenges of Islamic banking in the digital era.

\section{RESEARCH METHOD}

This paper analyzes the real condition with SWOT method. SWOT analysis is a comprehensive assessment of the strengths (strengths), weaknesses (weaknesses), opportunities (opportunities), and threats (threats) of a company [6]. Or in other words, S-W-O-T is used to assess the strengths and weaknesses of the resources owned by the company and external opportunities and challenges faced [2]. According to [1] all organizations have strengths and weaknesses in the functional area of business, which can be used as a basis for the objectives and determination of an organization's strategy. So, SWOT analysis is an instrument that is useful in conducting a strategy analysis, in the context of this article is intended to assess the existence of Islamic banking in the midst of 
the rapid flow of technology in digital, so it is expected to minimize the weaknesses in a banking institution and reduce the impact of threats that arise and must be faced.

\section{RESULT AND DISCUSSION}

\section{A. Islamic Banks in Running their Business}

Sharia banking operations in Indonesia have stretched for the last twenty-five years. Government Regulation Number 72 of 1992 supports the birth of profit sharing based business activities. This continues to strengthen with the birth of Law Number 7 of 1992 concerning Banking, although it still uses the term profit sharing with a broader understanding of Islamic banks that are relatively broader than profit sharing banks. It was not until 1998 that Law Number 10 of 1998 was born concerning Amendment to Law Number 7 of 1992 concerning Banking. This Act regulates in more detail the legal basis and types of businesses that can be operated and implemented. The law provides direction for conventional banks to open sharia branches or even convert themselves totally into Islamic banks. (Antonio, Syafi'I, 2001). Then was Act No. 23 of 1999 concerning Bank Indonesia. This Act also stipulates that Bank Indonesia can carry out monetary control based on Sharia principles.

The economic crisis that occurred since mid-1997 proved that banks operating with Sharia principles could survive amid the fluctuation of the exchange rate and highinterest rates. This fact is supported by the characteristics of Sharia bank operations which prohibit interest (usury), transactions that are not transparent (gharar) and speculative (maysir). With this reality, the development of Islamic banking is expected to increase the resilience of the national banking system in such a way as to create a resilient economy.

In order to guarantee legal certainty for stakeholders and at the same time provide confidence to the community by using Sharia Bank products and services, Law Number 21 of 2008 concerning Sharia banking was born. This Sharia Banking Act regulates the type of business, Sharia implementation provisions, business feasibility, distribution of funds, and prohibitions on Islamic Banks and Sharia Business Units which are part of Conventional Commercial Banks.

In this Act, the Sharia Bank is a Bank that carries out its business activities based on Sharia Principles. The Sharia Principle is the principle of Islamic law in banking activities based on a fatwa issued by an institution that has authority in the stipulation of a fatwa in the field of sharia. the institution which has this authority is the National Sharia Board (DSN) of the Indonesian Ulema Council (MUI). The principles and principles of running Sharia Banking business activities are based on Sharia Principles, economic democracy, and prudential principles.

For the development of its business, Islamic banks can combine, merge and take over Islamic banks after obtaining permission from Bank Indonesia. The Bank resulting from the Merger or Consolidation is required to become a Sharia Bank. (Article 17) Islamic banks in conducting Funds Distribution business must have confidence in the willingness and ability of prospective
Recipient Customers. Facility to pay off all obligations on time. To obtain confidence as referred to in paragraph (1), Sharia Banks and/ or UUS must make a careful assessment of the character, capabilities, capital, collateral and business prospects of prospective Facility Recipient Customers.

Islamic banks are prohibited from conducting business activities that are contrary to the Sharia Principles, carrying out activities of buying and selling shares directly in the capital market, carrying out capital participation and conducting insurance business activities, except as a marketing agent for sharia insurance products. The advantages and differences with conventional banks are that Islamic banks must have a Sharia Supervisory Board recommended by the Indonesian Ulema Council. DPS is responsible for providing advice and advice to the board of directors and overseeing the activities of the Bank to comply with Sharia Principles.

Thus the chances of Islamic banks are large enough to develop their business by providing facilitation to customers related to the progress of Fintech. This is insofar as it does not conflict with sharia principles.

\section{B. Fintech in Banking}

Technological progress is running very fast. many aspects are affected by the progress of ICT., ref [10] argues with his creative destruction theory that entrepreneurial values will create new markets through new methods. Proven The use of digital technology in the lives of everyday Indonesian people has turned out to change people's behavior in almost all aspects of life, such as buying and selling online (e-commerce), digital social interaction, electronic books, electronic newspapers, public transportation (taxis and motorbikes ), tourism support services, and also financial technology [11]. This data is also supported by a quantitative study which states that the use of digital information technology has helped the Indonesian people to run the economy more effectively and efficiently than before, especially in the financial sector, especially banking [8].

Financial Technology (fintech) in Indonesian becomes a very promising commodity in today's financial business. Fintech in Bank Indonesia Regulation No 19/12 / PBI / 2017 is categorized as; 1) Payment System, 2) Market Support, 3) Investment Management and Risk Management, 4) Loans, Financing and Capital Supply, and 5) Other financial services

At first, this fintech was only about borrowing money, as stipulated in POJK number 77 / POJK.01 / 2016 concerning Information Technology-based Borrowing and Borrowing Money. But in the end, Bank Indonesia expanded the scope of fintech. Because Bank Indonesia has a view of financial innovation that is efficient, safe, smooth and reliable, it will be able to support economic growth in Indonesia

This further strengthens the performance of banks in providing services to customers through financial technology information systems. In line with the above opinion, financial technology is considered to be an important factor in encouraging Indonesia's financial 
inclusion and digital banking [5]. Similarly, Sutojo (1997: 119) states that electronic data processing technology, which is now developed into financial technology has helped banks in speeding and accuracy in processing data on business operations and marketing their products.

In line with the above opinion, the application of information systems is very influential on the banking industry, where the application of information systems to the banking industry has a tremendous impact given the banking industry is one of the industries with the highest level of dependence on activities of collecting, processing, analyzing and report submission (information) needed to meet the needs of its customers [7].

Fintech was born and developed according to the demands of the times and economic markets, where the process of payment, transfer, buying and selling until financing is expected to become more practical, safe and modern. Transaction activities can now be done electronically through smartphones, tablets or other handheld devices. Thus, the presence of fintech is to complete the chain of financial transactions and to strengthen the financial ecosystem, and not replace the role of traditional financial institutions. Fintech supports the role of banks or financial institutions in providing financial services to customers, helping customers in making financial decisions, reducing operational costs and risk of loss (for example due to bad loans) and developing the market because fintech itself is one of the means to improve the marketing of a product in the middle financial industry, primarily because online product marketing is increasingly favored by the public.

For the sake of customer safety and comfort, the fintech organizer must fulfill the first provisions, an entity that is a legal entity as evidenced by the deed of establishment. Second is the payment service provider (PJSP) is the party that carries out or is responsible for processing payment transactions. This transaction mechanism itself is specifically regulated in Bank Indonesia Regulation number 19/08 / PBI / 2017 concerning the National Payment Gate. In its operation, the fintech provider and PJSP work together to ensure the implementation of this fintech.

Government efforts through Bank Indonesia, in carrying out Law No. 8 of 1999 concerning consumer protection, ensure the quality of the fintech system through a pilot test with the Regulatory sandbox. This aims to ensure the mechanism of consumer protection in the implementation of fintech in accordance with the provisions, as well as risk management and the precautionary principle to maintain monetary stability. In addition regulatory sandbox also tests the funds used to ensure that it is free from criminal acts of money laundering, as well as preventing the financing of terrorism. The implementation of fintech is very tangent to the provisions stipulated in Law No. 11 of 2008 concerning Information and Electronic Transactions. fintech is mostly application based which can be installed on consumer smartphones, which have the ability to read personal data stored on the cell phone and send it to the server. So that this fintech provider can freely access the data as an effort to protect its business continuity (Hedging) by ensuring consumers comply with their obligations but must maintain and protect customer privacy data.

Fintech currently has many functions that are not only as an online financial transaction service. The research results of the Indonesian FinTech Association reported that currently fintech companies in Indonesia are still dominated by payment companies (44 percent), aggregators (15 percent), financing (15 percent), financial planners for personal and corporate $(10$ percent $)$, crowdfunding ( 8 percent $)$ and others ( 8 percent).

\section{SWOT Analysis}

1. Strength Analysis

The use of fintech in customer service by Islamic banking is a competitive capital in the trading industry, the power analysis is as follows:

1) The ability of product facilitation services to be more effective and efficient, because it can simplify, simplify, and control the process with limited human resources. With technology, a bank is able to shorten the process of applying for a loan, so that the credit and facilities that have been promised can also be immediately enjoyed by customers.

2) Ability to improve the quality of services provided to consumers can be better, ranging from transferring data from application forms into the system (data entry), prospective customer data analysis (credit analysis), to card delivery.

3) The ability to reduce and reduce operational costs. So that it is more economical for operational costs and marketing costs because banking institutions have enough to collaborate with financial technology service providers in offering banking products to the public

4) The ability to store, record and analyze customer data more easily, so that it helps banks maintain customer relationships, better deal with consumer complaints,

5) Ability to develop products/ services will be more suitable for consumers. Therefore, at present, there are various types of credit with different features and facilities that represent the interest and lifestyle of the market segment

6) Ease of access to banking data services in large sizes and the ease of making transactions anytime and anywhere. 24-hour services, such as mobile banking, internet banking, SMS banking and call banking [9].

7) The ability to reach all walks of life who have access to the internet.

\section{Weaknesses Analysis}

Concerning to the weakness, the fintech which will be implemented in Islamic banking institutions has the following weakness analysis:

1) Weaknesses of supporting facilities and infrastructure. The use of fintech is needed by a conducive internet connection, both in terms of access speed and stable server in sending data files, because financial transactions will take place smoothly when internet 
access is not interrupted. Likewise, there is still an imbalance in access to banking services because the communication technology infrastructure is not evenly distributed between regions.

2) Technology crime. The use of information technology has the weakness of the emergence of online crime actions such as wiretapping, burglary, and cybercrime in financial transactions. So as to make people hesitant to make online transactions. Whereas what they need is getting comfort and security. Therefore, the presence of institutions that play a role in supervision, policymakers such as the Financial Services Authority, Bank Indonesia, the Ministry of Information and Communication and other relevant institutions are very much needed. (Law No. 21 of 2011).

3) Illegal practice, not all financial technology service providers have licenses to conduct financial transactions in a systematic and legal manner. So that it is possible for the occurrence of authority abuse practices or transactional irregularities, which actually harm and do not make it safer and more comfortable for customers. But on the other hand, strict regulation in the era of market disruption has become a barrier for technology companies. For technology companies, disruptions can become barriers to entry, for example, because business models are not known in existing regulations. While the incumbent side (old players), usually asks regulators to apply the same strict regulations for newcomers even though it is not in accordance with the business model on the grounds of fair competition. Whereas when disruption of innovation occurs in the financial sector, regulationmaking does not seem to answer the needs and becomes a threat because it blocks the entry of new entrants. Even sometimes imposing regulations that should not be applied to the perpetrators of the newcomer. Regulators themselves always consider the security and protection aspects of consumers as absolute values.

4) Community knowledge of financial technology that is relatively low allows them to not be able to maximally access fintech/ banking services. So that the government, in this case, the OJK, and BI, collaborate with banking institutions and financial technology service providers need to conduct socialization and education as well as increase the literacy of the use of financial technology.

\section{Opportunities Analysis}

The opportunities of financial technology implemented in Islamic banking institutions has the following analysis of opportunities:

1) Public awareness grows to store and borrow financial needs through banking services because it is considered safer and more profitable with the expectation of high-interest rates when saving funds and relatively affordable interest costs when making bank loan transactions.
2) Regulators, evaluators, and protectors, the Financial Services Authority (OJK) as a health center for controlling the financial industry play a role in ensuring the security and comfort of the community in trying. So that OJK with its authority can minimize banking crime using fintech services.

\section{Threat Analysis}

Beside those all, in Islamic banking law concept, fintech implemented in Islamic banking institutions has the following threat analysis:

1) The use of increasingly sophisticated technology by providers of financial technology services, without being accompanied by an increase in the quality of banking human resources, makes inequality in serving the community using banking services. This is because the existence of fintech is possible institutionally to weaken the banking / sharia banking function. In order to safeguard the security and protection of consumers, the issuance of POJK Number 77 Year 2016. This is to avoid the practice of shadow banking with the Peer to Peer Lending model. Namely the use of fintech as a lender (lending) and recorded in the balance sheet or On Balance Sheet.

2) The trend of globalization and openness in transnational transactions allows financial technology service providers to be increasingly diverse. So that the business competition authorities around the world have big challenges because the innovation disruption model is carried out in a variety of ways including mergers and acquisitions. Likewise, the collaboration of business actors between countries one another, especially the boundaries between legal jurisdictions become vague. This is related to the presence and utilization of big data in business. The negative side of big data is anti-competitive practices. This has the potential to harm consumers because businesses can control the market by acquiring business actors outside the relevant market by looking at the analysis of big data. Moreover, the use of big data plus algorithms, such as artificial intelligence (artificial intelligence), which makes it easier for businesses to predict market trends and optimize business processes.

3) A serious threat associated with fintech for banking/ sharia is cybercrime. Hacker attacks need to be watched out. Because the principle of banking is to provide comfortable services and safe consumer protection. Mckinsey (2016) predicts the trend in the banking industry in the next 10 years to grow very fast. In addition, there is a shift in customer expectations and digital technology is expected to cause major changes and provide a different consumer profile for the banking industry. Therefore Big data, machine learning, and crowdsourcing must be a major force in a company's risk management, especially in helping to identify and reduce the emergence of new risks, such as the risk of simultaneous effects of global influences and cyber-attacks. So there is a need for 
strict local and international regulation/ regulation in regulating all aspects of this industry

4) The unfavorable political situation in Indonesia, which influences relatively high inflation, causes financial / financing institutions to be more careful in channeling loans to the public. To ensure customer safety and comfort. The use of fintech in banking requires legal certainty. the presence of the state is needed both in educating and providing supervision on citizen services.

\section{CONCLUSION}

After analyzing the strengths, weaknesses, opportunities, and threats to the implementation of fintech on Islamic banking, it can be concluded that the use of fintech has a good opportunity to improve the quality of services and development of sharia banking business in Indonesia. However, the application of fintech also contains challenges for banks. The presence of many fintech raises a more variation financing model with lower costs and fast service. So that the existence of the role of banking institutions can be displaced/ threatened.

\section{REFERENCES}

[1] David, F. R. 2006. Manajemen strategis. Edisi ke Sepuluh, Jakarta: Penerbit Salemba Empat.
[2] Hartono, J. 2005. Sistem informasi strategik untuk keunggulan kompetitif. Yogyakarta: Penerbit Andi Offset.

[3] https://www.mckinsey.com/industries/automotive-andassembly/our-insights/disruptive-trends-that-willtransform-the-auto-industrydiankses 8 Agustus 2018

[4] Jogiyanto, 2005, Sistem Informasi Strategik untuk Keunggulan Kompetitif, Penerbit Andi Offset, Yogyakarta.

[5] Julianto, P. A. 2016. "Fintech", cara perbankan penuhi kebutuhan nasabah. Kompas. Diakses 8 Agustus 2018. Tersedia di http://bisniskeuangan.kompas.com.

[6] Kotler, P., dan G. Armstrong. 2008. Prinsip-prinsip pemasaran jilid 1. Jakarta: Penerbit Erlangga.

[7] Kurnia., Supriyadi, dan Masjono. 2015. Pengaruh hubungan pemanfaatan aplikasi core banking system terhadap kinerja individu karyawan PT. Bank BRI Syariah. Jurnal Akuntansi, Keuangan dan Perbankan (Account) 1 (3): 247-254.

[8] Margaretha, F. 2015. Dampak electronic banking terhadap kinerja perbankan Indonesia. Jurnal Keuangan dan Perbankan 19 (3): 514-524.

[9] Rahadi., dan Zanial. 2015. Analisis technology acceptance model pada industri perbankan. Jurnal Sistem Informasi (JSI) 7 (2): 837-851

[10] Schumpeter, J.A., 1934 (2008), The Theory of Economic Development: An Inquiry into Profits, Capital, Credit, Interest and the Business Cycle, translated from the German by Redvers Opie, New Brunswick (U.S.A) and London (U.K.): Transaction Publishers.

[11] Siregar, A. 2016. Financial technology tren bisnis keuangan ke depan. Infobanknews. Diakses 8 Agustus 2018. Tersedia di http://infobanknews.com. 